\title{
MOBILE SCANNER ADOPTION ANALYSIS BETWEEN EMPLOYMENT AND EDUCATIONAL BACKGROUND - AN ANALYSIS OF LOGISTIC REGRESSION
}

\author{
Indra Surya Permana ${ }^{1}$, Taufik Hidayat ${ }^{2}$, Rahutomo Mahardiko ${ }^{3}$ \\ ${ }^{1}$ Department of Economic Science, Universitas Nahdlatul Ulama Cirebon, Indonesia \\ ${ }^{2}$ Department of Computer Engineering, Universitas Wiralodra, Indonesia \\ ${ }^{3}$ Department of Software Service, Platinumetrix Pte. Ltd, Indonesia
}

\section{A R T I C LE IN F O}

\section{History of the article:}

Received April 15, 2021

Revised Mei 27, 2021

Accepted Mei 27, 2021

Published June 10, 2021

\section{Keywords:}

Regression Analysis

Mobile Scanner Technology

Smartphone

Mobile Scanner Adoption

\section{ABSTRACT}

As of today, the mobile apps may be downloaded everywhere. The development of mobile apps depends on the type of the work. An increasing use of mobile app is scanner apps due to an easy use. This paper presents the regression analysis on employment and educational background of the mobile scanner app because this research used category in the questionnaire. The use of logistic regression is to prove that any different comparisons are detected between employment and educational background so that the use of mobile scanner can be optimally used. The results show that educational background and employment have vital roles for mobile scanner adoption. This study also proves that previous researches on mobile scanner adoption were true for UTAUT model and comparison analysis.

\section{Correspondece:}

Taufik Hidayat,

Department of Computer Engineering

Universitas Wiralodra, Indonesia,

Email : thidayat.ft@unwir.ac.id

\section{INTRODUCTION}

The use of smartphone is increasing rapidly in Indonesia from time to time. As of today, the ownership of smartphone is almost equal of the number of total mobile phone used [1]. It means that mostly people in Indonesia uses smartphone as mobile device to communicate and get other things done [2].

About $85 \%$ of total population in Indonesia already owned mobile phone with any type, while the smartphone ownership itself raised from only $43 \%$ from total mobile phone owned up to $94 \%$ in 2019 of total population in comparison of $96 \%$ total mobile phone owned [2]. This proves that almost of mobile phone owned in Indonesia in 2019 are smartphone and it became important device for most Indonesian users.

As for smartphone's operation system used in Indonesia, there are almost no competition due to the number of total android operating system used in Indonesia reach out up from $76 \%$ in 2016 to $92 \%$ in 2020 of total percentage mobile operating system used in Indonesia [2]. The only operating system that is able to catch up is iOS even though the gap is still far behind [3].
Table 1 is several most downloaded digital image scanner apps in Google play.

\begin{tabular}{|c|c|c|c|c|}
\hline Apps & Download & $\begin{array}{l}\text { Published } \\
\text { by }\end{array}$ & $\begin{array}{l}\text { Output } \\
\text { File }\end{array}$ & OCR \\
\hline $\begin{array}{c}\text { Camscanne } \\
\text { r HD }\end{array}$ & $100,000,000+$ & INSTIG & PDF & Yes \\
\hline $\begin{array}{c}\text { Adobe } \\
\text { Scan:PDF }\end{array}$ & $10,000,000+$ & Adobe & PDF & Yes \\
\hline Office Lens & $10,000,000+$ & $\begin{array}{l}\text { Microsoft } \\
\text { Corporatin }\end{array}$ & $\begin{array}{l}\text { PDF, JPG, } \\
\text { onenote }\end{array}$ & Yes \\
\hline Clear Scan & $10,000,000+$ & $\begin{array}{l}\text { Indi Mobile } \\
\text { App }\end{array}$ & PDF, JPG & Yes \\
\hline $\begin{array}{l}\text { Camera } \\
\text { Scanner to } \\
\text { PDF }\end{array}$ & $10,000,000+$ & Tap-Mobile & PDF & Yes \\
\hline $\begin{array}{c}\text { Google } \\
\text { Drive }\end{array}$ & $5,000,000,000+$ & Google LLC & PDF & No \\
\hline
\end{tabular}

The latest researches on mobile scanner adoption had proven the positive results. The UTAUT analysis for mobile scanner adoption education and employment had positive effects compared to age, gender, experience, habit, and 
so on using Partial Least Square-Structural Equation Modelling (PLS-SEM) [5]. While, the comparison analysis on mobile phone scanner technology adoption showed that employment/work purpose is main reason for adoption rather than education using two-way ANOVA analysis [6]. So that, this research aim is to prove that the combination of employment and education may deliver better adoption for mobile phone scanner.

This paper will follow some sections. The next section is our literature regarding this study purpose. The following section discusses our method to reach the aim and shows the results. The last section is conclusions and limitation of the study.

\section{LITERATURE REVIEW}

Several research about smartphone's app have been conducted. There is discussion about smartphone user segmentation resulted some segments [7], among them is called utilitarians which use primarily and spended most of time on productivity apps with such age ranges [8]. Other study revealed that productivity apps is important, but not creating addiction [9]. While some other observe behavioral intentions toward apps [10] or users comparison with or without apps in their daily activities [11], but very few had discussed about productivity apps, especially within this article which will discuss influences of educational background and employment on the tendency of productivity apps usage, in this case digital mobile scanner [12].

\section{RESEARCH METHOD}

This research used quantitative approach with data collection from questionnaires with logistic regression model [13] because we use categorical that converted to number as dependent variable [14]. Below is the research flowchart:

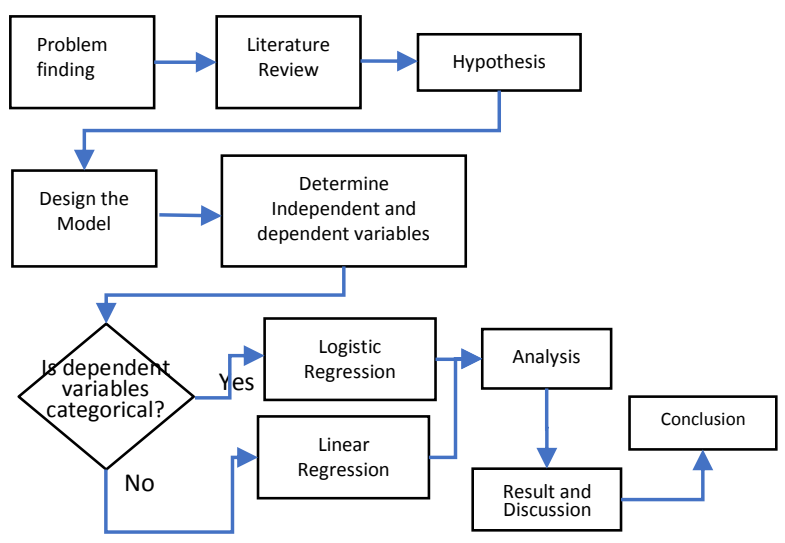

Figure 1. Research Logistic Regression

\section{Sampling}

- Variabels in this research consisted of educational background (ED), employment (EM) as independent variables and digital mobile scanner usage (DMS) as dependent variables [15]. About 340 respondents accross several big cities in Indonesia from various backgrounds participated in this research but reduced to 310 due to lack of completed informations [16]. The employment status that has been collected came from numerous background so we divided it into only 5 categories, i.e: unemployment, student, employee, self employeed, and entrepreneur. As for education background, we categorized in from high school up to doctoral (Ph.D) degree, while it is considered to represent the user of Portable Digital Scanner through the smartphone.

\section{Regression Logistic Analysis}

Hypotheses testing that conducted in this article consist of two as follows:

$H_{1}$ :Education background has significant effect to usage of smartphone's digital mobile scanner apps

$\mathrm{H}_{2}$ :Employment has significant effect to usage of smartphone's digital mobile scanner apps

Below is the basic function of logistic regression model in this research [17]:

$$
\ln \left(\frac{\hat{p}}{1-\hat{p}}\right)=\beta_{0}+\beta_{1} \cdot E D+\beta_{2} \cdot E M
$$

If $\hat{p}$ is probability of the event from dependent variable $D M S=1$ then, with simple algebraic calculation, we have [18]:

$$
\hat{p}=\frac{b^{\left(\beta_{0}+\beta_{1} \cdot E D+\beta_{2} \cdot E M\right)}}{b^{\left(\beta_{0}+\beta_{1} \cdot E D+\beta_{2}, E M\right)}+1} \text { for } 0<\hat{p}<1
$$

As of odds ratio (OR) for effect of each independent variables EDU and EM to dependent variable DMS in the logistic regression, the defined formula as follows [19]:

$$
\text { Odds Ratio }=e^{\beta_{1} \cdot E D+\beta_{2} \cdot E M}
$$

Wald statistic is used in this article for assessment alternative, where similar to t-test in linear regression [20]. It tested significance of each coefficients of independent variables [21]. This Wald statistic is later compared with $\chi^{2}$ from table depended on DF (degree of freedom) each test is run. The wald statistic formula is as follows [22]: 


$$
W_{j}=\frac{\beta_{j}^{2}}{S E_{\beta_{j}}^{2}}
$$

Where $\beta_{j}=\beta_{0}+\beta_{1} . E D+\beta_{2} . E M$

Logistic regression in this article used Cox and Snell $R^{2}$ and Nagelkerke $R^{2}$ rather than measured as normal $R^{2}$ as of index of goodness of fit assessment which can be conducted as follows [23]:

$$
\begin{aligned}
& R^{2}=1-\left(\frac{L_{0}}{L_{M}}\right)^{\frac{2}{n}} \\
= & 1-e^{2\left(\ln \left(L_{0}\right)-\ln \left(L_{M}\right)\right) / n}
\end{aligned}
$$

L0 and LM are the likelihoods for the model being fitted, where the difference between Cox and Snell and Nagelkerke is only the maximum value of Cox and Snell approach is only about 0.75 and Nagelkerke is equal to 1 .

\section{Data Conversion and Coding}

Data from each variable are converted into categorical as nominal and ordinal type of data values as follows:

Table 2. Data Conversion

\begin{tabular}{ccc}
\hline Variable & Description & $\begin{array}{c}\text { Categorical } \\
\text { Values }\end{array}$ \\
\hline DMS & Using DMS apps & 1 \\
& Not using DMS apps & 0 \\
\hline EDU & High School & 1 \\
& Associate Degree & 2 \\
& Bachelor & 3 \\
& Master & 4 \\
EM & PhD & 5 \\
\hline & Unemployment & 1 \\
& Student & 2 \\
& Employee & 3 \\
& Self Employed & 4 \\
& Entrepreneur & 5 \\
\hline
\end{tabular}

The number of categorical value in DMS and EM column represents the nominal type which does not have any rank or better value each other, while in the EDU variables represents the ordinal type which have rank that the higher the value is, means the better.

\section{RESULTS AND DISCUSSION}

Detailed respondent's description about educational backgrounds, employments, and digital mobile scanner usage that collected from

\begin{tabular}{|c|c|c|c|c|c|}
\hline \multirow{3}{*}{$\begin{array}{c}\text { Education and } \\
\text { Employment }\end{array}$} & \multicolumn{4}{|c|}{ Using Digital Mobile Scanner } & \multirow{3}{*}{$\begin{array}{c}\text { Tot } \\
\text { al }\end{array}$} \\
\hline & \multicolumn{2}{|c|}{ Female } & \multicolumn{2}{|c|}{ Male } & \\
\hline & No & Yes & No & Yes & \\
\hline High School & 34 & 50 & 17 & 83 & 184 \\
\hline Unemployed & 11 & 4 & 2 & 7 & 24 \\
\hline Student & 21 & 42 & 14 & 68 & 145 \\
\hline Employee & 1 & 4 & 1 & 7 & 13 \\
\hline Entrepreneur & 1 & & & 1 & 2 \\
\hline Associate Degree & & 3 & 1 & & 4 \\
\hline Student & & 1 & & & 1 \\
\hline Employee & & 1 & & & 1 \\
\hline Entrepreneur & & 1 & 1 & & 2 \\
\hline Bachelor & 19 & 17 & 9 & 32 & 77 \\
\hline Unemployed & 3 & 2 & 2 & 1 & 8 \\
\hline Student & 1 & 7 & & 10 & 18 \\
\hline Employee & 13 & 7 & 5 & 17 & 42 \\
\hline Entrepreneur & 2 & 1 & 2 & 1 & 6 \\
\hline Self Employed & & & & 3 & 3 \\
\hline Master & 13 & 10 & 7 & 14 & 44 \\
\hline Unemployed & 1 & 2 & 1 & 2 & 6 \\
\hline Employee & 11 & 6 & 4 & 9 & 30 \\
\hline Entrepreneur & 1 & & 2 & & 3 \\
\hline Self Employed & & 2 & & 3 & 5 \\
\hline PhD & & & & 1 & 1 \\
\hline Employee & & & & 1 & 1 \\
\hline Grand Total & 66 & 80 & 34 & 130 & 310 \\
\hline
\end{tabular}
questionnaires can be seen in table 3 :

Table 3. Respondents Description

Table 4 is the result of Logistic Regression

\begin{tabular}{|c|c|c|c|c|}
\hline Description & Values & DF & P-Value & Explanation \\
\hline Total Samples & \multicolumn{4}{|c|}{310} \\
\hline $\begin{array}{l}\text { Not using DMS } \\
\text { apps }\end{array}$ & \multicolumn{4}{|c|}{100} \\
\hline $\begin{array}{c}\text { Using DMS } \\
\text { apps }\end{array}$ & \multicolumn{4}{|c|}{210} \\
\hline $\begin{array}{l}\text { Variable in the } \\
\text { Equations (Step } \\
0 \text { ) before } \\
\text { inserting } \\
\text { independents } \\
\text { variables }\end{array}$ & & 1 & 0.000 & \\
\hline Slope (B) & 0.742 & & & \\
\hline Standard Error & 0.121 & & & \\
\hline Wald & 37.29 & & & \\
\hline $\begin{array}{l}\text { Odd Ratio / Exp } \\
\text { (B) }\end{array}$ & 2.100 & & & \\
\hline $\begin{array}{l}\text { Variables not in } \\
\text { the Equation }\end{array}$ & & & & \\
\hline $\begin{array}{l}\text { Educational } \\
\text { Background }\end{array}$ & 5.049 & 1 & 0.025 & \\
\hline Employment & 13.221 & 1 & 0.000 & \\
\hline Iteration history & & & & $\mathrm{DF}=\mathrm{N}-\mathrm{k}-1$ \\
\hline $\begin{array}{c}\text { Step 1-2 log } \\
\text { likelihood }\end{array}$ & $\begin{array}{c}375.69 \\
3\end{array}$ & & & $\begin{array}{c}=310-2- \\
1=307\end{array}$ \\
\hline
\end{tabular}
of the model.

Table 4. Results Regression 


\begin{tabular}{|c|c|c|c|c|}
\hline $\begin{array}{l}\text { Step 2-2 log } \\
\text { likelihood }\end{array}$ & $\begin{array}{c}375.32 \\
0\end{array}$ & & & \multirow{3}{*}{$\begin{array}{c}\chi_{\text {table }}^{2} \\
(D F=307) \\
=348.86\end{array}$} \\
\hline $\begin{array}{l}\text { Step 3-2 log } \\
\text { likelihood }\end{array}$ & $\begin{array}{c}373.32 \\
0\end{array}$ & & & \\
\hline $\begin{array}{l}\text { Step 4-2 log } \\
\text { likelihood }\end{array}$ & $\begin{array}{c}373.32 \\
0\end{array}$ & & & \\
\hline $\begin{array}{l}\text { Omnibus } \\
\text { (Maximum } \\
\text { Likelihood) } \\
\chi^{2} \\
\end{array}$ & 14.536 & 2 & 0.001 & $\begin{array}{c}\chi_{\text {table }}^{2} \\
(\mathrm{DF}=2)=5.99 \\
1\end{array}$ \\
\hline \multicolumn{5}{|c|}{ Pseudo R Square } \\
\hline Cox \& Snell $R^{2}$ & 0.46 & & & $\begin{array}{l}\text { independent } \\
\text { variables } \\
\text { ability to } \\
\text { predict is } 46 \\
\% \text { based on } \\
\text { Cox \& Snell } \\
\text { approach }\end{array}$ \\
\hline Nagelkerke $\mathrm{R}^{2}$ & 0.64 & & & $\begin{array}{l}\text { independent } \\
\text { variables } \\
\text { ability to } \\
\text { predict is } 64 \\
\text { based on } \\
\text { Nagelkerke } \\
\text { approach }\end{array}$ \\
\hline \multicolumn{5}{|c|}{ Goodness of Fit } \\
\hline $\begin{array}{lr}\text { Hosmer } & \text { and } \\
\text { Lemeshow } & \text { Test } \\
\chi^{2} & \\
\end{array}$ & 11.057 & 5 & 0.05 & $\begin{array}{c}\chi_{\text {table }}^{2} \\
(D F=5)=11.0 \\
705\end{array}$ \\
\hline \multicolumn{5}{|c|}{ Result } \\
\hline $\begin{array}{l}\text { Percentage } \\
\text { Correct of Not } \\
\text { using DMS Apps }\end{array}$ & $14.0 \%$ & & & \\
\hline $\begin{array}{l}\text { Percentage } \\
\text { Correct of using } \\
\text { DMS Apps }\end{array}$ & $91.4 \%$ & & & \\
\hline $\begin{array}{l}\text { Accuracy of } \\
\text { Model }\end{array}$ & $66.5 \%$ & & & \\
\hline \multicolumn{5}{|l|}{$\begin{array}{l}\text { Equation } \\
\text { Variables }\end{array}$} \\
\hline \multicolumn{5}{|l|}{$\begin{array}{l}\text { Education } \\
\text { Background }\end{array}$} \\
\hline $\operatorname{Exp}(B)$ & 1.157 & & 0.16 & \\
\hline Standar Error & 0.104 & & & \\
\hline \multicolumn{5}{|l|}{ Employment } \\
\hline $\operatorname{Exp}(B)$ & 1.282 & & 0.002 & \\
\hline Standar Error & 0.080 & & & \\
\hline
\end{tabular}

From table 4 above, the number of total samples are 310 , which divided into two category that are people who did not use Digital Mobile Service desribe as "0" as many as 100 respondents and who did use it as "1" with total 210 respondents. -2 log Likelihood $(373.320)<\chi_{\text {table }}^{2}(348.86)$ which means accept null-hypothesis that indicate model above with independent variables is Fitted with the data. As the value of $\chi^{2}(14.536)>\chi_{\text {table }}^{2}(\mathrm{DF}=2)=5.991$ with significance $p(0,001)$, then it means that nullhypothesis again is rejected that indicated education and employment have significant effect toward desire to use digital mobile scanner application [24] with total effect of $64 \%$ (with Nagelkerke R2 approach) [25]. As of Goodness of Fit test, we obtained $\chi^{2}$ from Hosmer and Lemeshow Test 11.057 < $X_{\text {table }}^{2}(\mathrm{DF}=5)=11.0705$ which indicated that nullhypothesis where the model is fit, is accepted. It means following hypothesis testing for the model can be done because there are no significant difference between model and observation values and can represent the actual conditions with overall percentage of the model's accuracy in this article is $66.5 \%$. While we accept both hypotheses testing from each independent variables, the effect of them respectively, are shown from the value of Odds Ratio (OR) for each independent variables namely EDU and EM. The logistic regression function in this article is as follows:

$\ln \left(\frac{\hat{p}}{1-\hat{p}}\right)=1.557+0.146 E D U+0.249 E M$

$P$ value of Wald statistic for EDU as education background is $<0.05$ means that educational background give no partial effect to desire to use digital mobile scanner apps, while on the contrary, $p$ value of Wald statistic for EM as employment is $>0.05$ which indicates that employment have significant partial effect of the observed desire to use digital mobile scanner apps. From the Table 1 and equation above, EDU give the result that people with higher education give 1.157 times the chance of using Digital Mobile Scanner (DMS) [26] And EM shows that as better employment give chances of 1.282 times of using DMS [27].

\section{CONCLUSION}

As for the result shown above, although we decided to accept both Null Hypotheses, it came with the interesting results. It indicated that smartphone usage in the modern day is not only for basic and social needs, but also served as work devices that can be relied on. People with higher education and better employment status tend to use Digital Mobile Scanner likely rather than people with less education and the one with less employment. One of significant development of smartphone today is the use of camera as modern digital scanner with a form of application as a replacement of old conventional scanner that can be downloaded anytime. Many people use it to increase their productivity in work and educational purposes. This study delivers the perspective of how educational background and 
employment affect the usage of their smartphone, especially for advanced use such as camera utilization as documents scanner. It resulted that educational background has no partial effect but rather as supportive factor when combined with better employment.

\section{LIMITATION OF THE STUDY}

This study has some limitations. First limitation is that the variables are educational background and employment. Second limitation is that data conversion can be changed for better analysis. Third limitation is that bigger respondent can be national level. Hence, all limitations can be done for future works.

\section{REFERENCES}

[1] Statistics, "Smartphone market in Indonesia Statistics and facts," 2020, [Online]. Available:

https://www.statista.com/topics/5020/smartph ones-in-indonesia/.

[2] Statcounter, "Mobile Operating System Market Share Indonesia," 2020, [Online]. Available: https://gs.statcounter.com/osmarket-share/mobile/indonesia/2016.

[3] T. Regan et al., "Does mindfulness reduce the effects of risk factors for problematic smartphone use? Comparing frequency of use versus self-reported addiction," Addict. Behav. vol. 108, p. 106435, Sep. 2020.

[4] P. Roma and M. Vasi, "Diversification and performance in the mobile app market: The role of the platform ecosystem," Technol. Forecast. Soc. Change, vol. 147, no. July, pp. 123-139, Oct. 2019.

[5] I. S. Permana, T. Hidayat, and R. Mahardiko, "Users' intentions and behaviors toward portable scanner application - Do education and employment background moderates the effect of UTAUT main theory?," 2nd International Conference on Enhanced Research and Industrial Application 2020, Yogyakarta, pp. 1-10, 2020.

[6] I. S. Permana, T. Hidayat, and R. Mahardiko, "Mobile phone scanner technology adoption A comparison analysis," The 3rd International Conference on Applied Science and Technology, Padang, In Press. 2020.

[7] M. K. Onyeajuwa, "Institutions and consumers: Assertion of ordinary consumer interest in the Nigerian digital mobile telecommunications market," Telecomm. Policy, vol. 41, no. 7-8, pp. 642-650, Aug. 2017.

[8] K. Swani, "To app or not to app: A businessto-business seller's decision," Ind. Mark. Manag., pp. 1-13, Jun. 2020.
[9] J. Nie, P. Wang, and L. Lei, "Why can't we be separated from our smartphones? The vital roles of smartphone activity in smartphone separation anxiety," Comput. Human Behav., vol. 109, p. 106351, Aug. 2020.

[10] F. Liu, Z. Zhang, and L. Chen, "Mediating effect of neuroticism and negative coping style in relation to childhood psychological maltreatment and smartphone addiction among college students in China," Child Abuse Negl., vol. 106, no. December 2019, p. 1-14. 2019.

[11] G. N. Mourra et al., "Using a smartphone while walking: The cost of smartphoneaddiction proneness," Addict. Behav., vol. 106, no. February, p. 106346, Jul. 2020.

[12] J. M. Müller, B. Pommeranz, J. Weisser, and K. Voigt, "Digital, Social Media, and Mobile Marketing in industrial buying: Still in need of customer segmentation? Empirical evidence from Poland and Germany," Ind. Mark. Manag., vol. 73, no. January, pp. 70-83, Aug. 2018

[13] H. Fukunishi, M. Nishiyama, Y. Luo, M. Kubo, and Y. Kobayashi, "Alzheimer-type dementia prediction by sparse logistic regression using claim data," Comput. Methods Programs Biomed., p. 105582, Jun. 2020.

[14] A. K. Y. Tang, "A systematic literature review and analysis on mobile apps in m-commerce: Implications for future research," Electron. Commer. Res. Appl., vol. 37, no. July, pp. 114, Sep. 2019.

[15] J. Á. Martín-Baos, R. García-Ródenas, M. L. López-García, and L. Rodriguez-Benitez, "Discrete choice modeling using Kernel Logistic Regression," Transp. Res. Procedia, vol. 47, pp. 457-464, 2020.

[16] D. Seka, B. S. Bonny, A. N. Yoboué, S. R. Sié, and B. A. Adopo-Gourène, "Identification of maize (Zea mays L.) progeny genotypes based on two probabilistic approaches: Logistic regression and naïve Bayes," Artif. Intell. Agric., vol. 1, pp. 9-13, Mar. 2019.

[17] W. N. Picoto, R. Duarte, and I. Pinto, "Uncovering top-ranking factors for mobile apps through a multimethod approach," J. Bus. Res., vol. 101, no. June 2018, pp. 668674, Aug. 2019.

[18] K. Verma and D. K. Sharma, "Calculation of non-linearity and algebraic degree of constructed boolean function," in 2017 2nd IEEE International Conference on Recent Trends in Electronics, Information \& Communication Technology (RTEICT), vol. 2018-Janua, pp. 501-505, May. 2017. 
[19] R. Verma et al., "Estimation of Sex in Forensic Examinations using Logistic Regression and Likelihood Ratios," Forensic Sci. Int. Reports, vol. 594, no. lii, p. 100118, Jul. 2020.

[20] S. Nusinovici et al., "Logistic regression was as good as machine learning for predicting major chronic diseases," J. Clin. Epidemiol., vol. 122, pp. 56-69, Jun. 2020, doi: 10.1016/j.jclinepi.2020.03.002.

[21] R. de A. Araújo, N. Nedjah, A. L. I. Oliveira, and S. R. d. L. Meira, "A deep increasingdecreasing-linear neural network for financial time series prediction," Neurocomputing, vol. 347, pp. 59-81, 2019.

[22] S.-H. Moon and Y.-H. Kim, "An improved forecast of precipitation type using correlation-based feature selection and multinomial logistic regression," Atmos. Res., vol. 240, p. 104928, Aug. 2020.

[23] Q. Yu, "The maximum likelihood estimator under the exponential distribution with rightcensored linear regression data," Stat. Probab. Lett., vol. 165, p. 108846, Oct. 2020.

[24] A. Jadhav and J. Weis, "Mobile phone ownership, text messages, and contraceptive use: Is there a digital revolution in family planning?" Contraception, vol. 101, no. 2, pp. 97-105, Feb. 2020.

[25] D. Quaglione, N. Matteucci, D. Furia, A. Marra, and C. Pozzi, "Are mobile and fixed broadband substitutes or complements? New empirical evidence from Italy and implications for the digital divide policies," Socioecon. Plann. Sci., vol. 71, p. 100823, Sep. 2020.

[26] M. Yadav, Y. Joshi, and Z. Rahman, "Mobile Social Media: The New Hybrid Element of Digital Marketing Communications," Procedia - Soc. Behav. Sci., vol. 189, pp. 335-343, May 2015.

[27] T. V. Anh, H. T. T. Nguyen, and N. T. M. Linh, "Digital Transformation," in Proceedings of the 2019 The World Symposium on Software Engineering - WSSE 2019, no. 2017, pp. 119-124, 2017. 